\title{
Effect of seaweed extract application on wine grape yield in Australia
}

\author{
Tony Arioli $^{1,2}$ (D) $\cdot$ Scott W. Mattner ${ }^{3,4} \cdot$ Graham Hepworth $^{5} \cdot$ David McClintock $^{6} \cdot$ Rachael McClinock $^{6}$
}

Received: 6 October 2020 / Revised and accepted: 15 February 2021 / Published online: 8 March 2021

(C) The Author(s) 2021

\begin{abstract}
Seaweed extracts are agricultural biostimulants that have been shown to increase the productivity of many crops. The aim of this study was to determine the effect of a seaweed extract from the brown algae Durvillaea potatorum and Ascophyllum nodosum as a soil treatment on the yield of wine grapes grown in Australian production and climate conditions. This study used a series of seven field experiments (2012-2017), across five locations, in three Australian states and four cultivars, and analysed data using a linear mixed model approach. The analysis revealed that recurring soil applications of the seaweed extract significantly increased wine grape yield by an average of $14.7 \%$ across multiple growing years that experienced climate extremes. Partial budget analysis showed that the use of the seaweed extract increased profits depending on the grape cultivar. This study is the most extensive investigation of its type in Australian viticulture to understand the effect of a soil-applied seaweed extract on wine grape production.
\end{abstract}

Keywords Vitis vinifera $\cdot$ Productivity $\cdot$ Biostimulant $\cdot$ Economic sustainability $\cdot$ Stress tolerance

\section{Introduction}

Grape production underpins the Australian wine industry, which contributed over AU\$45 billion to the national economy in 2019 (Wine Australia 2020). Maintaining grape productivity, and farm profitability, is challenging in Australia, particularly due to increasing climate volatility (Webb et al. 2008, 2011, 2012). One example of a climate-related impact is that vineyards are experiencing earlier grape ripening (Webb et al. 2012; Palliotti et al. 2014). At the same time, there is greater impetus for industry to develop agronomic systems that minimise chemical inputs, and increase environmental and social stewardship, crop productivity and economic sustainability (Christ and Burrit 2013; Galinsky et al. 2016; Zambon et al. 2018).

Tony Arioli

tonyarioli@hotmail.com

1 R\&D Department, Seasol International, Bayswater, Victoria, Australia

2 School of Life and Environmental Sciences, Deakin University, Geelong, Victoria, Australia

3 VSICA Research, Toolangi, Victoria, Australia

4 School of Life Sciences, La Trobe University, Bundoora, Victoria, Australia

5 Statistical Consulting Centre, The University of Melbourne, Carlton, Victoria, Australia

6 R\&D Viticultural Services, Mildura, Victoria, Australia
Seaweed extracts belong to the broader category of agricultural biostimulants, which have the capacity to sustainably enhance yield and quality across crops and farming systems with different soil types by increasing plant tolerance to abiotic and biotic stresses and improving nutrient use (Shukla et al. 2019; Rouphael and Colla 2020). For example, greenhouse and field studies have demonstrated that seaweed extracts applied as foliar or soil treatments can increase yield in sugarcane, strawberries, vegetables and tomatoes (Mattner et al. 2018; Shukla et al. 2019; Arioli et al. 2020; Hussain et al. 2021). Several field trials using seaweed extracts in grapes have also reported yield increases (Norrie et al. 2002; Norrie and Keathley 2006; Holden et al. 2008; Anderson 2009; Kok et al. 2010; El-Kareem and El-Rahman 2013). These grape field trials have predominately used seaweed extract made from Ascophyllum nodosum, applied as a foliar spray to canopies across two or three testing seasons.

Research using Arabidopsis, soybean and tomato plants has demonstrated that the application of seaweed extract can improve plant tolerance to abiotic stress such as drought (Martynenko et al. 2016; Santaniello et al. 2017; Goni et al. 2018). Molecular studies using seaweed extracts have uncovered aspects of their mechanism of action. For example, the application of seaweed extract to Arabidopsis plants initiates the production of reactive oxygen species (Cook et al. 2018; Islam et al. 2020) and the activation of transcription networks with diverse functionalities, represented by genes involved in different plant phytohormone pathways, defense responses and the phenylpropanoid pathway, among others (Nair et al. 
2012; Goni et al. 2016; Jithesh et al. 2019; Islam et al. 2020; Omidbakhshfard et al. 2020). Other soil microbe studies have demonstrated that the application of seaweed extracts can alter the representation of the microbiota located in the soil and at the rhizosphere, and these changes coincided with enhanced plant growth and yield (Renaut et al. 2019; Hussain et al. 2021). Developing a greater knowledge of the mechanisms by which seaweed extracts improve crop yields and tolerance of environmental stress is an important scientific driver for the adoption of seaweed extracts and other biostimulants by industry. This is not the primary aim of the current paper; however, and readers are referred to a subset of other reviews that consider this topic (Arioli et al. 2015; Shukla et al. 2019, 2021; Boukari et al. 2020).

The expanding biostimulant industry is advocating for the testing of agricultural biostimulants in real-world conditions (Ricci et al. 2019). Additional field research is needed (i) to investigate the effectiveness of agricultural biostimulants across extended seasons and environments, and (ii) to provide real-world insights into their mechanisms of action. Furthermore, few studies have considered the effects of seaweed extracts on the economics of commercial crop production. Analysis has shown that the integrated of use of seaweed extracts with conventional farming inputs (fertilisers or herbicides) increased gross margins to varying levels in corn, rice and potato (Pal et al. 2015; Singh et al. 2015; Nayak et al. 2020; Zarzecka et al. 2020). Similarly, Mattner et al. (2018) found that regular applications of a seaweed extract to soil increased revenue from fruit by AU $\$ 0.30$ plant $^{-1}$ in strawberry.

The aim of this study was to determine the effect of a seaweed extract on wine grape yield when applied as a soil treatment in Australian climate and agronomic production conditions. Our hypothesis was that grape vines treated with repeated soil applications of a different type of seaweed extract (made from two seaweeds Durvillaea potatorum and Ascophyllum nodosum) would increase grape yield across multiple growing seasons and locations, and profits for growers. Our approach was to apply a statistical analysis to a series of experimental field trials. The research trials were conducted across an extended number of growing seasons (2010-2017), at different production areas (five), using red and white grape cultivars (four). Wine grape yield was the main assessment parameter in all the trials. The uniqueness of this research was the number of field trials and the timeframe used to assess the effectiveness of a soil-applied seaweed extract on wine grape yield in an Australian production setting.

\section{Materials and methods}

A multi-location and multi-year (2012-2017) study was conducted in the Australian viticulture industry evaluating the use of a commercially available seaweed extract (Seasol, Seasol
International, Victoria) made from two large cold-water species: Durvillaea potatorum (native to the southern hemisphere) and Ascophyllum nodosum (native to the northern hemisphere), using an alkaline extraction process. Detailed information about the seaweed extract such as composition, mineral content and manufacture has been previously published (Arioli et al. 2015; Wite et al. 2015). Field trials were conducted in commercial vineyards on large areas (2-70 ha) across five geographically diverse locations (Fig. 1) and with different grape cultivars (Table 1). The seaweed extract treatment was applied at 5 or $10 \mathrm{~L} \mathrm{ha}^{-1}$, with the number of applications ranging from three to eight, applied to the soil through irrigation water (at a concentration of approximately 1:400) at different phenological stages of the crop during the growing season (as described for the trial site). The treatment dosage was chosen because of efficacy studies in other Australian field trials (Mattner et al. 2013, 2018; Farnsworth and Arioli 2018; Arioli et al. 2020). The parameter assessed was wine grape yield.

\section{Field trial locations and design}

Trials were in inland Australia in irrigated growing regions with warm climates (Fig. 1). In all trials, control rows (grower standard practice) only received the vineyard's normal soil nutrient, irrigation and fungicide program throughout the season. All rows treated with the seaweed extract also had the same nutrient, irrigation and fungicide program applied. Petiole nutrient analysis (AWRI 2014) was used to prepare the vineyard fertiliser programs as recommended by industry guidelines (Coombe and Dry 1992b; AWRI 2014). Irrigation outputs were applied evenly to all control and seaweed extract rows by the vineyard trial manager on each site, with the assistance of weather forecasts and soil moisture monitoring devices. All vineyards had sufficient access to water for irrigation during extreme heat events.

To minimise field trial variation due to past agronomic management, each trial site was set up within a uniformly managed vineyard block. For each field trial, the soil irrigation system (with a fertigation injection capacity) was adapted to deliver individual treatments at the required dosage to the specific replicated rows. At application, the irrigation line was inspected for the dark colour of the seaweed extract (or for clear liquid for the water control) to confirm the irrigation system was delivering the treatments to the appropriate rows. Individual trial sites were selected based on a consistent production history with uniform soil type, vine age and spacing, cultivar planting, management practices (such as a pruning and nutrient program) and vine health. Soil types at trials sites were representative of their production areas (Coombe and Dry 1992a). Soil type at trial sites 1, 2 and 3 was calcareous earth, brown to red-brown loamy sand. Soil type at trial sites 4 and 5 was hard red duplex soils, and brownish surface soils ranging from loamy sand to clay loam. 


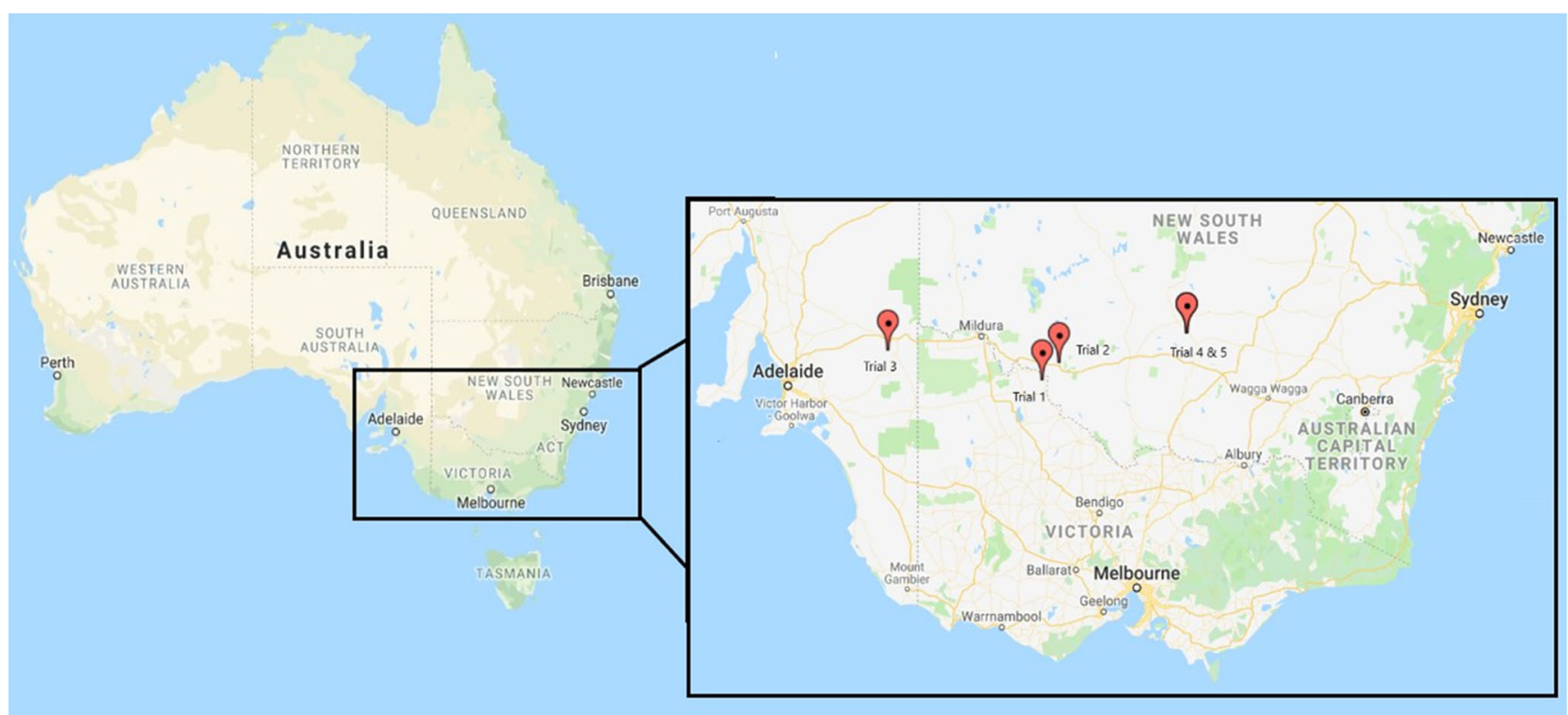

Fig. 1 Locations of trials evaluating the effectiveness of soil treatment with a seaweed extract in Australian viticulture

\section{Trial site 1: Chardonnay (white grape cultivar)}

The trial site was at an established commercial vineyard near Kenley in Victoria. The vineyard was planted in 2002 and comprised 55 rows of Chardonnay (1.7 ha) on a two-wire cordon trellis system under drip irrigation. The seaweed extract treatment was soil-applied at a rate of $10 \mathrm{~L} \mathrm{ha}^{-1}$ during various phenological stages during the two years of the trial. In 2012/2013, treatments were applied at woolly bud (E-L 3) and 10-cm shoot growth (E-L 12), with six subsequent treatments at 20- to 30-day intervals. In 2013/2014, treatments were applied at budburst (E-L 4), flowering (E-L 19), fruit set (E-L 27) and veraison (E-L 34).
The trial design compared three replicated control plots with three treatment plots. There were three rows in each plot (Table 1).

\section{Trial site 2: Semillon (white grape cultivar)}

The trial site at Balranald, New South Wales, was planted in 1995 and comprised 70 rows of Semillon (6.71 ha) on a twowire cordon trellis system under drip irrigation. In 2012/2013 and 2013/2014, the seaweed extract was applied by drip irrigation to soil at a rate of $5 \mathrm{~L} \mathrm{ha}^{-1}$ during three phenological stages: budburst (E-L 4), flowering (E-L 19) and fruit set (E-L

Table 1 Field trial summary of locations, cultivars, vintages and treatments used in an analysis evaluating the effectiveness of a seaweed extract (SE) on yield in wine grape crops in Australia

\begin{tabular}{|c|c|c|c|c|c|c|}
\hline Trial site & Location & Cultivar & Year & Treatments & Plots & Rows \\
\hline \multirow[t]{4}{*}{1} & \multirow[t]{4}{*}{ Kenley, VIC } & \multirow[t]{4}{*}{ Chardonnay } & \multirow[t]{2}{*}{$2012 / 2013$} & 8 applications of $10 \mathrm{~L} \mathrm{ha}^{-1} \mathrm{SE}$ & 3 & 3 \\
\hline & & & & Control & 3 & 3 \\
\hline & & & \multirow[t]{2}{*}{$2013 / 2014$} & 4 applications of $10 \mathrm{~L} \mathrm{ha}^{-1} \mathrm{SE}$ & 3 & 3 \\
\hline & & & & Control & 3 & 3 \\
\hline \multirow[t]{4}{*}{2} & \multirow[t]{4}{*}{ Balranald, NSW } & \multirow[t]{4}{*}{ Semillon } & \multirow[t]{2}{*}{$2012 / 2013$} & 3 applications of $5 \mathrm{~L} \mathrm{ha}^{-1} \mathrm{SE}$ & 1 & 3 \\
\hline & & & & Control & 1 & 3 \\
\hline & & & \multirow[t]{2}{*}{$2013 / 2014$} & 3 applications of $5 \mathrm{~L} \mathrm{ha}^{-1} \mathrm{SE}$ & 1 & 3 \\
\hline & & & & Control & 1 & 3 \\
\hline \multirow[t]{2}{*}{3} & \multirow[t]{2}{*}{ Loxton, SA } & \multirow[t]{2}{*}{ Merlot } & \multirow[t]{2}{*}{$2013 / 2014$} & 3 applications of $5 \mathrm{~L} \mathrm{ha}^{-1} \mathrm{SE}$ & 1 & $1-3$ \\
\hline & & & & Control & 1 & $1-3$ \\
\hline \multirow[t]{2}{*}{4} & \multirow[t]{2}{*}{ Tharbogang, NSW } & \multirow[t]{2}{*}{ Merlot } & \multirow[t]{2}{*}{$2014 / 2015$} & 4 applications of $10 \mathrm{~L} \mathrm{ha}^{-1} \mathrm{SE}$ & 3 & $3-4$ \\
\hline & & & & Control & 3 & 4 \\
\hline \multirow[t]{2}{*}{5} & \multirow[t]{2}{*}{ Tharbogang, NSW } & \multirow[t]{2}{*}{ Cabernet Sauvignon } & \multirow[t]{2}{*}{$2016 / 2017$} & 3 applications of $10 \mathrm{~L} \mathrm{ha}^{-1} \mathrm{SE}$ & 3 & $3-4$ \\
\hline & & & & Control & 4 & $2-3$ \\
\hline
\end{tabular}


27). The trial design compared one control plot with one treatment plot, and there were three rows per plot (Table 1).

\section{Trial site 3: Merlot (red grape cultivar)}

The trial site was on an established vineyard in the Riverland of South Australia, near Loxton. The vineyard was planted in 2002 and comprised 52 rows of Merlot (6.61 ha) on a twowire cordon trellis system under drip irrigation. The seaweed extract was applied through the irrigation system to soil at a rate of $5 \mathrm{~L} \mathrm{ha}^{-1}$ during the three phenological stages: budburst (E-L 4), flowering (E-L 19) and fruit set (E-L 27). The trial design compared one control plot with one treatment plot, and there were three rows per plot (Table 1).

\section{Trial site 4: Merlot (red grape cultivar)}

The trial site at Tharbogang, New South Wales, was planted in 2007 and comprised 30 rows (10.34 ha) of Merlot on a singlewire cordon trellis system under drip irrigation. In 2014/2015, the seaweed extract was applied to soil at a rate of $10 \mathrm{~L} \mathrm{ha}^{-1}$ at budburst (E-L 4), flowering (E-L 19), fruit set (E-L 27) and veraison (E-L 34). The trial design compared three replicated control plots with three treatment plots, and there were three to four rows per plot (Table 1).

\section{Trial site 5: Cabernet Sauvignon (red grape cultivar)}

The largest trial site, at a separate vineyard at Tharbogang, NSW, was planted in 1993 and comprised 89 rows (69 ha) of Cabernet Sauvignon on a double-wire cordon trellis system under drip irrigation. In 2016/2017, the seaweed extract was applied to soil at a rate of $10 \mathrm{~L} \mathrm{ha}^{-1}$ at 4-cm growth (E-L 9), flowering (E-L 19) and fruit set (E-L 27). The trial design compared four replicated control plots with three treatment plots, and there were two to four rows per plot (Table 1).

\section{Measurements}

\section{Grape yield}

Yields were determined by harvesting grapes by hand from vines within a 2-m-long sub-section (spanning $1 \mathrm{~m}$ from either side of the main trunk), which was randomly selected within each plot. The yield assessment involved removing all the grape bunches (along all cordon wires), collecting them into standardised bins, weighing them using scales to two decimal places, and converting data to grape yield $(\mathrm{kg})$ per metre $(\mathrm{m})$. Yield per hectare was calculated using the formula:

Yield $\left(\mathrm{t} \mathrm{ha}^{-1}\right)=\frac{\text { vine spacing }(\mathrm{m}) \times \text { row spacing }(\mathrm{m})}{10,000} \times \frac{\text { yield }\left(\mathrm{kg} \mathrm{m}^{-1}\right)}{1000}$

\section{Partial budget analysis}

Economic analysis of the effect of the use of the seaweed extract was based on the method described by Szparaga et al. (2019) except (i) the currency used was Australian dollars (AU\$) and (ii) the economic assessment was calculated for each wine grape cultivar used in the study. Calculations were based on (i) the value of the yield increases from the use of the seaweed extract and (ii) the costs to purchase and apply the product in Australia. The relevant wholesale grape prices for each cultivar, region and year were sourced from published industry information (Murray Valley and Swan Hill Winegrape Industry Development Committee 2021 (trial 1); Riverina Winegrape Growers 2021 (trials 2, 4, 5); Vinehealth Australia 2021 (trial 3)). The application costs for the seaweed extract were based on frequency and rate described for each trial. The only differential cost was for the liquid seaweed extract concentrate (AU\$40/10L). In Australia, mechanical harvesting of wine grapes is charged by the metre, so the harvest costs were the same for the treatment and the control. The watering, nutrition and pest control programs were identical for the treatment and control, so these costs were the same. Application of the seaweed extract occurred at the same time as normal fertigation practices, so this did not incur additional costs in water, operational costs or labour.

\section{Statistical analysis of grape yield data}

In this series of experimental trials, the treatment and control plots generally alternated (or similar), and the analysis was based on a randomisation assumption. A separate analysis of variance (ANOVA) was first performed on each trial in turn. For trial 1, the ANOVA divided the data into three levels of variation: between plots, between rows within plots and between years within rows. The variation between plots was then used to compare treatments. For trials 2 and 3, to construct separate ANOVAs required an assumption that the two years or the rows within plots provided genuine replication, but such an assumption was not necessary when combining the trials (see below). For trials 4 and 5, the ANOVA divided the data into two levels of variation: between plots and between rows within plots. The variation between plots was used to compare treatments. ANOVA was not applicable (NA) for trials containing one plot of each treatment and was noted in the ANOVA data.

An analysis combining all trials was then conducted. Because of the unequal numbers and different levels of variation in the individual trials, the analysis required a linear mixed model, which took these features of the data into account, and effectively provided a statistical analysis for the series of trials. For the mixed model, the fixed effect was treatment, and the random effects were trial and plot nested within trial. Row was initially included as random effect but 
was subsequently omitted because it interfered with numerical convergence of the REML algorithm. Calculation of differences and \% differences have used more decimal places than appear in the table; any apparent minor discrepancies are due to rounding. The analysis was conducted using Genstat 18th Ed. (VSNI, UK).

\section{Results}

\section{Grape yield}

Analysis of data from all the field trials showed that use of the seaweed extract significantly $(p<0.001)$ increased grape yield by $1.4 \mathrm{tha}^{-1}$ or $14.7 \%$ compared with the control (Table 2). The trial at Kenley, VIC., was the only individual experiment that showed significant differences between the treatments, although in all trials the difference was in the same positive direction.

\section{Partial budget analysis}

An analysis of the field trials found the economic effect of using seaweed extract in wine grape production was positive and the increase in profitability varied for wine grape cultivars (Fig. 2). Increased profits ranged from AU $\$ 136 \mathrm{ha}^{-1}$ for Cabernet Sauvignon in trial 5 to $\mathrm{AU} \$ 467 \mathrm{ha}^{-1}$ for Merlot in trials 3 and 4.

\section{Discussion}

This series of experiments comprehensively demonstrated that the use of a seaweed extract as a biostimulant increased yields of multiple cultivars of wine grapes by 10-18\% under diverse environments, and across multiple locations and seasons in Australia. Before this study, there were few scientific studies on the effectiveness of seaweed extracts for grape production in Australia. Wilson (2001) found that the use of a seaweed extract reduced the critical freezing point of plant cells in the shoots of grape vines. Field studies by Scarlett (2009) and Scarlett et al. (2011) showed that treatment with seaweed extracts reduced berry desiccation in wine grapes. Anderson (2009) reported a different seaweed extract improved fruit quality and vine vigour in two grape cultivars (Cabernet Sauvignon and Cabernet Franc). The current study is the first publication using a series of experiments to characterise the effectiveness of seaweed extract on wine grape yield in Australia.

Field trials around the world have demonstrated the positive effects of seaweed extracts on yield in table grapes (Norrie et al. 2002; Norrie and Keathley 2006; Kok et al. 2010; de Carvalho et al. 2019). These studies mostly applied seaweed extracts to grape plants as foliar applications. In contrast, the current series of experiments showed that a seaweed extract increased grape yields when applied to the soil through drip irrigation systems. For wine grapes, several publications have reported the efficacy of seaweed extracts for enhanced grape quality, photosynthesis performance, stomatal conductance, tolerance to low water availability and tolerance to biotic stress (Salvi et al. 2019, 2020; Frioni et al. 2019, 2021; Tombesi et al. 2020). However, there is a scarcity of research about the effect of seaweed extracts on yield in wine grapes (Holden et al. 2008; Anderson 2009).

Seaweed extracts are made from different types of seaweeds (particularly A. nodosum) and manufactured using extraction processes such as alkaline or acid hydrolysis and cell fracture (Shukla et al. 2019; Boukari et al. 2020). The effects of seaweed extracts are not identical. For example, extracts made from the same seaweed (A. nodosum) but processed using different alkaline or neutral conditions were found to have different transcriptomic profiles in Arabidopsis (Goni et al. 2016). Similarly, different seaweeds (A. nodosum, D. potatorum) processed by the same alkaline extraction process generated different, though overlapping, transcriptomic responses (Islam et al. 2020). Because seaweed extracts are heterogeneous in composition, field trials are an important part of establishing efficacy. We are the first to report the results of wine grape yield studies using a seaweed extract processed from two seaweeds (D. potatorum and A. nodosum).

Some researchers have suggested that pretreatment with seaweed extracts is a mechanism for priming the stress response of plants (Santaniello et al. 2017; Islam et al. 2020). The wine grapes in our trials were given repeated soil

Table 2 Mean grapevine yield $\left(\mathrm{t} \mathrm{ha}^{-1}\right)$ at individual trial sites, and overall (CI confidence interval)

\begin{tabular}{|c|c|c|c|c|c|c|}
\hline Trial & Seaweed extract $\left(\mathrm{t} \mathrm{ha}^{-1}\right)$ & Control $\left(\mathrm{t} \mathrm{ha}^{-1}\right)$ & Difference $\left(\mathrm{t} \mathrm{ha}{ }^{-1}\right)$ & Difference $(\%)$ & $95 \% \mathrm{CI}$ for difference & $P$ value \\
\hline 1 & 13.4 & 11.7 & 1.6 & 13.8 & $(0.8,2.4)$ & 0.005 \\
\hline 2 & 14.5 & 13.1 & 1.3 & 10.0 & NA & NA \\
\hline 3 & 11.8 & 10.0 & 1.8 & 17.6 & NA & NA \\
\hline 4 & 5.5 & 4.9 & 0.5 & 11.0 & $(-1.3,2.4)$ & 0.47 \\
\hline 5 & 7.7 & 6.9 & 0.7 & 10.7 & $(-0.8,2.3)$ & 0.27 \\
\hline All & 10.7 & 9.3 & 1.4 & 14.7 & $(0.9,1.9)$ & $<0.001$ \\
\hline
\end{tabular}


Fig. 2 Economic benefit from the use of a seaweed extract (SE) in trials with different cultivars of wine grapes across Australia
Economics of wine grape field trials by cultivar

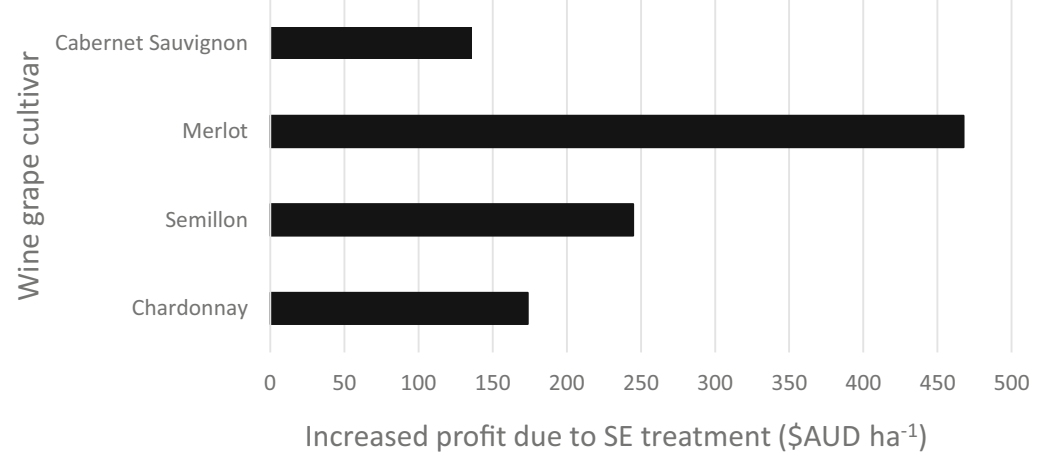

applications of seaweed extract during the growing seasons to potentially compound the beneficial effect. While the field trials assessed in several of the grape publications used grafted vines and a surfactant with the seaweed extract applications, the grape vines used in our research were not grafted and no surfactant was used. Some of the publications calculated grape yield based on bunch and berry weight and number of bunches per vine, while in our trials it was assessed directly.

It is unlikely that the improvements in yield demonstrated in our trials were due to a fertiliser effect of the seaweed extract. The seaweed extract used has been shown to have a low concentration of nutrients (Wite et al. 2015) and was highly dilute on application. The field trials were managed using a comparatively high nutrition program. Application of the seaweed extract has not been found to affect the nutrient content of soils (Mattner et al. 2018), and nutrient controls (solutions matching the nutrient composition of the seaweed extract) were shown to have no effect in stimulating plant growth (Yusuf et al. 2012).

There is substantial support for a mechanism of enhanced plant nutrient acquisition and accumulation when using seaweed extract (Crouch et al. 1990; Shukla et al. 2019). In grapes, seaweed extracts have been reported to increase nutrient uptake and translocation, and ammonium and potassium influxes at the root tip (Turan and Köse 2004; Mancuso et al. 2006; Mugnai et al. 2008). Drench application of the same seaweed extract used in this study has been found to significantly increase strawberry root length density (root length per volume soil) in the field, and this was directly correlated ( $r=$ $0.94)$ to significant increases in marketable fruit yield. A distinguishing feature in the current study is the application of seaweed extract directly to the soil through a fertigation system. In terms of dosage and frequency, the wine grape yield improvements found in the current study are comparable to strawberry and sugarcane field trials where monthly applications $\left(10 \mathrm{~L} \mathrm{ha}^{-1}\right)$ of the same seaweed extract significantly increased crop yields (Farnsworth and Arioli 2018; Mattner et al. 2018; Arioli et al. 2020). We hypothesise that the nutrient assimilation properties identified in seaweed extracts, in combination with repeated soil applications to potentially compound this effect, contributed to the significant increases in wine grape yield found in the current study. Further field research is needed to confirm this hypothesis.

The mode of action of the seaweed extract used in the current study is more complex than a single mechanism for increasing yield. Although not central to the yield investigation, we measured total anthocyanin content and shoot length to understand the mechanisms of action. We found increases in both these phenotypes (S1, S2), suggesting the application of the seaweed extract utilises different plant processes. Brown and Saa (2015) have hypothesised that biostimulants, including seaweed extracts, interact with plant signalling processes to reduce the extent of negative plant responses to stress and increase the allocation of biomass to the harvestable yield component. Such a mechanism of action could explain how biostimulants generate multiple positive phenotypes, as observed in the current work.

The timing of our trials coincided with Australia's hottest decade on record (2011-2020) based on mean temperature (BOM 2021). The increasing temperatures resulted in increased vineyard climate indices such as growing degree days and earlier wine grape maturity (Jarvis et al. 2017). At the trial locations, twelve weather records were set for different stresses (heat, cold, wettest and driest months, S3). In some cases, the climate stresses overlapped in the same season. Given that seaweed extracts improve plant tolerance of abiotic stresses (Shukla et al. 2019), it is possible the effectiveness of the seaweed extract was even more pronounced due to these weather extremes.

Growers relate well to larger scale field trials, and the biostimulant industry endorses the testing of seaweed extracts under real-world conditions (Ricci et al. 2019). However, field trials are inherently subject to experimental variation. In Australian viticulture, the variation in yield measurements can be substantial, as displayed by grower field estimates ranging from 25 to 40\% (Dunn and Martin 2003). In Australia, Anderson (2009) observed a considerable yield increase when applying seaweed extract to the Cabernet Franc cultivar but 
concluded the trial variation was too high to prove the result was statistically significant. For these reasons, field trials with seaweed extracts are not commonly undertaken at commercial vineyards and across different seasons and experimental locations.

In this study, we relied on a statistical analysis of a series of field trials conducted across an extended timeframe. This approach proved conclusive over the statistical analysis of our individual trials because of additional replications. A high number of replicates was also found to be necessary in strawberry field trials testing the effect of seaweed extract on yield (Mattner et al. 2018). These trials required 16 replicates to conclude that seaweed extract statistically increased yield under commercial conditions. In addition, our research across an extended number of growing seasons uncovered the efficacy of seaweed extract on wine grape yield is resilient. This finding parallels the positive effect of seaweed extract on sugarcane yield spanning four growing seasons (Arioli et al. 2020). Overall, our statistical findings contribute significantly to the limited scientific literature published about the use of seaweed extracts in Australian viticulture for yield improvement.

The move from conventional to more sustainable farming practices, such as the use of seaweed extracts as biostimulants, can be challenging for growers. In viticultural systems, research showed that growers are unlikely to adopt sustainable farm practices unless they offer environmental and economic/business advantages (Cullen et al. 2013; Forbes et al. 2013) or are driven by government policy (Kallas et al. 2010). Partial budget analysis from the current series of experiments showed that the use of seaweed extract was economically sustainable across diverse environments and cultivars in Australia because it increased revenue from wine grape yield far more than the cost of the application of the product. This is largely because no costly changes to infrastructure were needed, as growers could apply the seaweed extract to soil through their existing irrigation systems. Few studies have considered the economic impact of seaweed extracts on agricultural crop production (Pal et al. 2015; Singh et al. 2015; Mattner et al. 2018; Nayak et al. 2020; Zarzecka et al. 2020). Despite this, these studies corroborate the current study and have all showed positive economic effects from the use of seaweed extracts. Based on the analysis from the current study, the use of seaweed extract can be integrated into conventional viticulture operations in an economically way. Collectively, the environmentally compatible nature of seaweed extracts and their agronomic and economic attributes support their use in viticulture and in sustainable agriculture.

\section{Conclusions}

This study is the most comprehensive analysis of its type in Australian viticulture to investigate the effect of a seaweed extract biostimulant applied to soil through irrigation on wine grape production. The study demonstrated that seaweed extract treatments significantly improved wine grape yield by $14.7 \%$ across multiple growing years, four grape cultivars and in Australian environments experiencing climate stress. Furthermore, this investigation supports the recurring application of seaweed extract as an effective and economical practice that fits with the vision of sustainable agriculture.

Supplementary Information The online version contains supplementary material available at https://doi.org/10.1007/s10811-021-02423-1.

Acknowledgements The authors greatly acknowledge the vineyard staff who kindly assisted and offered expertise so the trials could be conducted scientifically at Australian vineyards.

Author contribution All co-authors contributed to the final version of the work and approved the manuscript for publication. TA: leading the field research, interpretation of data, and writing the manuscript; SWM: interpretation of data and writing the manuscript; GH: expert statistical analysis and writing the manuscript; RM and DM: performed all the field trial work.

Funding Research funding was provided by Seasol International Pty Ltd (Australia).

Data availability Available data is provided in the publication and as supplementary information.

\section{Declarations}

Conflict of interest Seasol International (SI) is the manufacturer of the seaweed extract in Australia. TA is an employee of SI and an Adjunct Associate Professor at Deakin University. All other authors are not employees of SI. The authors declare that the research was conducted in the absence of any financial relationship that could be construed as a potential conflict of interest. No funding was received to assist with the preparation or submission of this manuscript.

Open Access This article is licensed under a Creative Commons Attribution 4.0 International License, which permits use, sharing, adaptation, distribution and reproduction in any medium or format, as long as you give appropriate credit to the original author(s) and the source, provide a link to the Creative Commons licence, and indicate if changes were made. The images or other third party material in this article are included in the article's Creative Commons licence, unless indicated otherwise in a credit line to the material. If material is not included in the article's Creative Commons licence and your intended use is not permitted by statutory regulation or exceeds the permitted use, you will need to obtain permission directly from the copyright holder. To view a copy of this licence, visit http://creativecommons.org/licenses/by/4.0/.

\section{References}

Anderson G (2009) Seaweed extract shows improved fruit quality at McLaren Vale vineyard trial. Aust NZ Grapegrow Winemake 548: $17-22$

Arioli T, Mattner S, Winberg P (2015) Applications of seaweed extracts in Australian agriculture: past, present and future. J Appl Phycol 27: 2007-2015 
Arioli T, Hepworth G, Farnsworth B (2020) Effect of seaweed extract application on sugarcane production. Proc Aust Soc Sugar Cane Technol 42:393-396

AWRI (2014) Viticare on farm trials - manual 3.3 [online]. Australian Wine Research Institute (AWRI). https://www.awri.com.au/wpcontent/uploads/2014/09/on-farm-trials-manual-3-3.pdf. retrieved 17 January 2021

BOM (2021) Annual climate statement 2020: issued 8 Jan 2021. http:// www.bom.gov.au/climate/current/annual/aus/ retrieved 18 January 2021

Boukari MM, Barakate M, Bouhia Y, Lyamlouli K (2020) Trends in seaweed extract based biostimulants: manufacturing process and beneficial effect on soil-plant systems. Plants 9:359

Brown P, Saa S (2015) Biostimulants in agriculture. Front Plant Sci 6:671

Christ KL, Burrit RL (2013) Critical environmental concerns in wine production: an integrative review. J Clean Prod 15:233-242

Cook J, Zhang J, Norrie J, Blal B, Cheng Z (2018) Seaweed extract (Stella Maris $®$ ) activates innate Immune responses in Arabidopsis thaliana and protect host against pathogens. Mar Drugs 16:221

Coombe BG, Dry PR (1992a) Viticulture Volume 2: Practices, 2d edn. Winetitles, Adelaide

Coombe BG, Dry PR (1992b) Viticulture Volume 1: Resources, 2d edn. Winetitles, Adelaide

Crouch J, Beckett P, Van Staden J (1990) Effect of seaweed concentrate on the growth and mineral nutrition of nutrient stressed lettuce. $\mathrm{J}$ Appl Phycol 2:269-272

Cullen R, Forbes SL, Grout R (2013) Non-adoption of environmental innovations in wine growing. NZ J Crop Hort Sci 41:41-48

de Carvalho R, Pasqual M, de Oliveira Silveira H, de Melo P, Bispo D, Laredo R, de Agular Saldanha Lima L (2019) "Niágara Rosada" table grape cultivated with seaweed extracts: physiology, nutritional, and yielding behaviour. J Appl Phycol 31:2053-2064

Dunn G, Martin S (2003) The current status of crop forecasting in the Australian wine industry. Proceedings of the ASVO Seminar Series: Grapegrowing at the Edge; July 2003; Tanunda, Barossa Valley, SA, Australia; pp 4-8

El-Kareem GM, El-Rahman AM (2013) Response of Ruby seedless grapevines to foliar application of seaweed extract, salicylic acid and roselle extract. Hortsci J Suez Canal Univ 1:294-303

Farnsworth W, Arioli A (2018) Assessment of the yield of sugarcane following treatment with liquid seaweed extract (SEASOL $®$ ). Acta Hortic 1205:785-788

Forbes SL, Cullen R, Grout R (2013) Adoption of environmental innovations: analysis from the Waipara wine industry. Wine Econ Policy 2:11-18

Frioni T, Tombesi S, Quaglia M, Calderini O, Moretti C, Poni S, Gatti M, Moncalvo A, Sabbatini P, Berrios J, Palliotti A (2019) Metabolic and transcriptional changes associated with the use of Ascophyllum nodosum extracts as tools to improve the quality of wine grapes (Vitis vinifera cv. Sangiovese) and their tolerance to biotic stress. J Sci Food Agric 99:6350-6363

Frioni T, VanderWeide J, Pallioti, Tombesi S, Poni S, Sabbatini P (2021) Foliar vs soil application of Ascophyllum nodosum extracts to improve grapevine water stress tolerance. Sci Hortic 277:109807

Galinsky A, Newton SK, Vega RF (2016) Sustainability in the global wine industry: concepts and cases. Agric Agric Sci Proc 8:37-49

Goni O, Fort A, Quille P, Mckeown P, Spillane C, O’Connell S (2016) Comparative transcriptome analysis of two Ascophyllum nodosum extract biostimulants: same seaweed but different. J Agric Food Chem 64:2980-2989

Goni O, Quille P, O'Connell S (2018) Ascophyllum nodosum extract biostimulants and their role in enhancing tolerance to drought stress in tomato plants. Plant Physiol Biochem 126:63-73

Holden D, Johnson H, Ocafrain M, Norrie J (2008) Effect of seaweed extract on fruit set, yield, and quality in Pinot Noir wine grapes. In: Fidelibus M (Ed) Proceedings of the 35th Annual Meeting of the
Plant Growth Regulation Society of America; 3-7 August, 2008; San Francisco, California, USA

Hussain H, Kasinadhuni N, Arioli T (2021) The effect of seaweed extract on tomato plant growth, productivity and soil. J Appl Phycol. https:// doi.org/10.1007/s10811-021-02387-2

Islam M, Gan H, Ziemann M, Hussain H, Arioli T, Cahill D (2020) Phaeophyceaean (brown algal) extracts activate plant defense systems in Arabidopsis thaliana challenged with Phytophthora cinnamomi. Front Plant Sci 11:852

Jarvis C, Barlow E, Darbyshire R, Eckard R, Goodwin I (2017) Relationship between viticultural climatic indices and grape maturity in Australia. Int J Biometeorol 61:1849-1862

Jithesh M, Shukla S, Kant P, Joshi J, Critchley T, Prithiviraj B (2019) Physiological and transcriptomics analyses reveal that Ascophyllum nodosum extracts induce salinity tolerance in Arabidopsis by regulating the expression of stress responsive genes. J Plant Growth Regul 38:463-478

Kallas Z, Serra T, Gil GM (2010) Farmers' objectives as determinants of organic farming adoption: the case of Catalonian vineyard production. Agric Econ 41:409-423

Kok D, Bal E, Celik S, Ozer C, Karauz A (2010) The influences of different seaweed doses on table quality characteristics of cv. Trakya Ilkeren (Vitis vinifera L.). Bulg J Agric Sci 16:429-435

Mancuso S, Azzarello E, Mugnai S, Briand X (2006) Marine bioactive substances (IPA extract) improve foliar ion uptake and water stress tolerance in potted Vitis vinifera plants. Adv Hortic Sci 20:156-161

Martynenko A, Shotton K, Astatkie T, Petrash G, Fowler C, Neily W, Critchley T (2016) Thermal imaging of soybean response to drought stress: the effect of Ascophyllum nodosum seaweed extract. Springerplus 5:1393

Mattner S, Wite D, Riches D, Porter I, Arioli T (2013) The effect of kelp extract on seedling establishment of broccoli on contrasting soil types in southern Victoria, Australia. Biol Agric Hortic 29:258-270

Mattner S, Milinkovic M, Arioli T (2018) Increased growth response of strawberry roots to a commercial extract from Durvillaea potatorum and Ascophyllum nodosum. J Appl Phycol 30:2943-2951

Mugnai S, Azzarello E, Pandolfi C, Salamagne S, Briand X, Mancuso S (2008) Enhancement of ammonium and potassium root influxes by the application of marine bioactive substances positively affects Vitis vinifera plant growth. J Appl Phycol 20:177-182

Murray Valley and Swan Hill Winegrape Industry Development Committee (2021) Murray Darling \& Swan Hill Winegrapes Crush Reports. Murray Valley Winegrower Inc, Mildura. http:// www.mvwi.com.au/winegrape_crush_reports/murray_darling _ and_swan_hill_winegrape_crush_reports/ searched on 26 January 2021.

Nair P, Kandasamy S, Zhang J, Ji X, Kirby C, Benkel B, Hodges M, Critchley A, Hitz D, Prithiviraj B (2012) Transcriptional and metabolomic analysis of Ascophyllum nodosum mediated freezing tolerance in Arabidopsis thaliana. BMC Genomics 13:643

Nayak P, Biswas S, Dutta D (2020) Effect of seaweed extracts on growth, yield and economics of kharif rice (Oryza sativa L.). J Pharmacogn Phytochem 9:247-253

Norrie J, Keathley J (2006) Benefits of Ascophyllum nodosum marineplant extract applications to "Thompson Seedless" grape production. Acta Hortic 727:243-247

Norrie J, Branson T, Keathley P (2002) Marine plant extracts impact on grape yield and quality. Acta Hortic 594:315-319

Omidbakhshfard A, Sujeeth N, Gupta S, Omranian N, Guinan J, Brotman Y, Nikoloski Z, Fernie A, Mueller-Roeber B, Gechev T (2020) A biostimulant obtained from the seaweed Ascophyllum nodosum protects Arabidopsis thaliana from severe oxidative stress. Int J Mol Sci 21:474

Pal A, Dwivedi SK, Maurya PK, Kanwar P (2015) Effect of seaweed saps on growth, yield, nutrient uptake and economic improvement of maize (sweet corn). J Appl Nat Sci 7:970-975 
Palliotti A, Tombesi S, Silvestroni O, Lanari V, Gatti M, Poni S (2014) Changes in vineyard establishment and canopy management urged by earlier climate-related grape ripening: a review. Sci Hortic 178: $43-54$

Renaut S, Masse J, Norrie J, Blal B, Hijri M (2019) A commercial seaweed extract structured microbial communities associated with tomato and pepper roots and significantly increased crop yield. Microb Biotechnol 12:1346-1358

Ricci M, Tilbury L, Daridon B, Sukalac K (2019) General principles to justify plant biostimulant claims. Front Plant Sci 10:494

Riverina Winegrape Growers (2021) Grape price surveys. Riverina Winegrape Growers, Griffith. https://riverinawinegrapes.com.au/ services/grape-price-survey/ searched on 26 January 2021.

Rouphael Y, Colla G (2020) Editorial: biostimulants in agriculture. Front Plant Sci 11:40

Salvi L, Brunetti C, Cataldo E, Niccolai A, Centritto M, Ferrini F, Matti G (2019) Effects of Ascophyllum nodosum extract on Vitis vinifera: consequences on plant physiology, grape quality and secondary metabolism. Plant Physiol Biochem 139:21-32

Salvi L, Brunetti C, Cataldo E, Storchi P, Matti G (2020) Ecophysiological traits and phenylpropanoid profiling on potted Vitis vinifera L. cv Pinot Noir subjected to Ascophyllum nodosum treatment under post-veraison low water availability. Appl Sci 10:4473

Santaniello A, Scartazza A, Gresta F, Loreti E, Biasone A, Tommaso D, Piaggesi A, Perata P (2017) Ascophyllum nodosum seaweed extract alleviates drought stress in Arabidopsis by affecting photosynthetic performance and related gene expression. Front Plant Sci 8:1362

Scarlett N (2009) Reducing berry raisining in the vineyard: a vineyard case study in small-scale, on-farm research. Aust N Z Grapegrow Winemak 550:25-28

Scarlett N, Needs S, Howell K, Cooley N (2011) Berry desiccation: developing pre-emptive methods to adapt to heat spikes and dry conditions. Aust NZ Grapegrow Winemak 567:20-23

Shukla P, Mantin E, Adil M, Bajpai S, Critchley A, Prithiviraj B (2019) Ascophyllum nodosum-based biostimulants: sustainable applications in agriculture for the stimulation of plant growth, stress tolerance, and disease management. Front Plant Sci 10:655

Shukla P, Borza T, Critchley A, Prithiviraj B (2021) Seaweed-based compounds and products for sustainable protection against plant pathogens. Mar Drugs 19:29

Singh SK, Thakur R, Singh MK, Singh CS, Pal SK (2015) Effect of fertilizer level and seaweed sap on productivity and profitability of rice (Oryza sativa). Indian J Agron 60:69-74
Szparaga A, Kuboń M, Kocira S, Czerwińska E, Pawłowska A, Hara P, Kobus Z, Kwaśniewski D (2019) Towards sustainable agriculture agronomic and economic effects of biostimulant use in common bean cultivation. Sustainability 11:4575

Tombesi S, Frioni T, Sabbatini P, Poni S, Palliotti A (2020) Ascophyllum nodosum extract improves leaf thermoregulation by reducing stomatal sensitivity to VPD in Vitis vinifera L. J Appl Phycol. https://doi. org/10.1007/s10811-020-02336-5

Turan M, Köse C (2004) Seaweed extracts improve copper uptake of grapevine. Acta Agric Scand Sect B 54:213-220

Vinehealth Australia (2021) SA Winegrape Crush Survey. Vinehealth Australia, Adelaide. https://vinehealth.com.au/news-2/sawinegrape-crush-survey/ searched on 26 January 2021.

Webb L, Whetton P, Barlow W (2008) Climate change and winegrape quality in Australia. Clim Res 36:99-111

Webb L, Whetton P, Barlow W (2011) Observed trends in winegrape maturity in Australia. Glob Chang Biol 17:2707-2719

Webb L, Whetton P, Bhend J, Darbyshire R, Briggs P, Barlow W (2012) Earlier wine-grape ripening driven by climatic warming and drying and management practices. Nat Clim Chang 2:259-264

Wilson S (2001) Frost management in cool climate vineyards. Final report to Wine Australia project. University of Tasmania. UT 99/1 pp $1-34$

Wine Australia (2020) Australian wine sector 2019 at a glance. Wine Australia. https://www.wineaustralia.com/market-insights/ australian-wine-sector-at-a-glance; retrieved 17 January 2021

Wite D, Mattner S, Porter I, Arioli T (2015) The suppressive effect of a commercial extract from Durvillaea potatorum and Ascophyllum nodosum on infection of broccoli by Plasmodiophora brassicae. J Appl Phycol 27:2157-2161

Yusuf R, Kristiansen P, Warwick N (2012) Potential effect of plant growth regulators in two seaweed products. Acta Hortic 958:133138

Zambon I, Colantoni A, Cecchini M, Masconi GM (2018) Rethinking sustainability within the viticulture realtities integrating economy, landscape and energy. Sustainability 10:320

Zarzecka K, Gugała M, Sikorska A, Grzywacz K, Niewęgłowwski M (2020) Marketable yield of potato and its quantitative parameters after application of herbicides and biostimulants. Agriculture 10:49

Publisher's note Springer Nature remains neutral with regard to jurisdictional claims in published maps and institutional affiliations. 